\title{
An Ontology in Project Management Knowledge Domain
}

\author{
T.Sheeba, \\ Muscat College, \\ P.O.Box:2910, P.C:112, \\ Ruwi, Sultanate of Oman
}

\author{
Reshmy Krishnan, PhD. \\ Muscat College, \\ P.O.Box:2910, P.C:112, \\ Ruwi, Sultanate of Oman
}

\author{
M.Justin Bernard, \\ W.J. Towell Engineering, \\ P.O.BOX:1040, P.C:112, \\ Ruwi, Sultanate of Oman
}

\begin{abstract}
E-Learning is a process in which electronic medium is used to access the defined set of applications and processes. In eLearning environment, automatic classification of learning materials is essential due to lack of common vocabulary of the knowledge area in some context. Ontology has the potential to play an important role in representing an area of knowledge. This paper proposes ontology to automatic classification of learning materials to the Project Management knowledge area domain. This ontology aims to facilitate the search for learning materials within the given domain. The Project Management Body of Knowledge (PMBOK) was used to define the hierarchical structures of knowledge as it is intended to cover broad area of Project Management. The Rational Unified Process (RUP) was used to add axioms to define the relationships between the main concepts. Two specific examples were designed to show the automatic classification of learning materials. Experiments were performed using the OWL reasoner Pellet and editor Protégé 4.2 alpha version. The results of our performance evaluation show that the ontology is able to classify and locate learning materials from the Project Management area, according to the desired area, role, artifact and activity.
\end{abstract}

\section{Keywords}

Ontology; PMBOK; RUP; Project Management; Protégé 4.2 alpha

\section{INTRODUCTION}

With the development of World Wide Web (WWW), the increased popularity and use of its new web-based technologies has increased the number of learning environments, from simple learning resources repositories to more complex learning environments. In such learning environments, almost all the resources are provided through the computers and networks and students can learn anytime and anywhere. It can provide flexible and user-oriented learning environments to students [1].

This self-learning process can happen through many learning materials, such as slide shows, digital books, audio or video recordings, etc. These materials are designed for both on site and at distance learners to use on their own. It allows knowledge sharing within a common interest domain and stimulates independent learning. Project Management can be named as one of such subjects.

However, the self-learning environment can be challenging, even for the brightest and most motivated students in real knowledge acquisition. The difficulty in finding the desired learning materials according to the learner's range of knowledge themes and interest is one of these challenges.

Classification of learning materials according to their knowledge area scheme improves the accuracy of information retrieval significantly and allows users to browse the collection by subject. However, these classification mechanisms must use a common language that would allow knowledge sharing to occur effectively. The automated classification is relevant when people do not hold enough knowledge to identify the theme related to the learning materials due to lack of common vocabulary of the knowledge area [2]. Project engineers can be mentioned as an example.

Most knowledge areas as an example, the Project Management area have terminology problems. A terminology, as a general term for all kinds of controlled vocabularies, can help to clear up ambiguities in the terms used in the context of project management [3]. It is common that different development teams use different terms for the same concepts. Thus, it is likely that even professionals find some difficulty to search adequate learning materials due to lack of a common terminology.

In this context, ontologies have the potential to play an important role in defining the terms used to describe and represent an area of knowledge thus providing a common shared understanding of the structure of information among individuals or organizations, to enable reuse of domain knowledge, make domain assumption explicit, to separate domain knowledge from the operational knowledge and to analyze domain knowledge. It includes machine-interpretable definitions of basic concepts in the domain and relations among them [4].

Ontology describes a hierarchy of concepts related by subsumption relationships, suitable axioms are added in order to express relationships between concepts and to constrain their intentional interpretations. Ontologies can be used to describe a common vocabulary of terms and specification of their meaning to the knowledge area [5]. Through ontologies, hierarchical structures of themes related to the learning materials can be defined and also it is possible to add reasoning to this structure in order to help the automatic classification of learning materials within the defined hierarchy.

The main objective of this paper is to propose an ontology to automatic classification of learning materials related to the Project Management knowledge area. Also, this ontology aims to facilitate the search for learning materials within the given domain. The Project Management Body of Knowledge (PMBOK) [6] was used to define the hierarchical structures of knowledge. The absence of a recognized consensus on Project Management terminology has been a challenging task in building the PMBOK Guide, and in achieving an international consensus. The PMBOK is intended to cover broad area of Project Management. The Rational Unified Process (RUP) was used to add axioms to define the relationships between the main concepts and enable the reasoning to the PMBOK knowledge area.

The remainder sections of this paper are organized as follows: Section 2 presents the related work; Section 3 describes the details of the proposed ontology and its integration with the 
ontology for the classification of learning materials according to the PMBOK knowledge areas; Section 4 discuss some case studies and Section 5 concludes the paper.

\section{RELATED WORK}

There are several papers proposing ontologies for the Project Management area. This section presents these researches and their approaches.

PROMONT [7], is a project management ontology developed from the most notably upcoming DIN 69901 model to model project management specifications. It provides the basis of common understanding between projects related terms and methods and thus facilitate the management of projects accomplished in dynamic virtual environments.

A prototype ontological model [8] prescribed by the PRINCE2 ${ }^{\circledR}$ project management method is described for the project management processes. This prototype creates a representation of ontology in OWL as a collection of axioms. It was created using the Protégé 4 ontological modeling tool. This model is used in checking the compliance of suppliers stated methods with standards and supporting process model tailoring. However, it presents difficulties for domain experts as its reasoning rules can be counter-intuitive.

The concepts of e-Government project management are presented using ontology in this model [9]. It is applied in the productivity of e-Government project process which enables the knowledge reuse, collaboration and interoperability between all stakeholders related with the implementation of such type of projects.

PMBOK integrated with RUP is applied to create a model for software project management [10]. This integrated model addresses the possibility of automating a number of tasks for software development.

HCRN (hierarchical case retrieval network) [11] is used by the project managers to interlink decision making tasks. It provides a basis for experience management of decision making within project management processes by transforming decision situation to knowledge focus.

As there are several schemes proposed for ontologies in the Project Management area, there is not an ontology to classify materials according to the Project Management Engineering knowledge area. The next section discusses the proposal of an ontology to help solving this problem.

\section{PROPOSED ONTOLOGY}

This section presents an ontology for software Project Management based on PMBOK and its integration with RUP concepts to classify learning materials in the Project Management knowledge area. Some of the widely used ontology development tools include Ontolingua, Ontosaurus, WebOnto, Protégé, OntoEdit etc. In this area of ontology development, ontology editor Protégé 4.2 alpha is used as an appropriate language and development tools as it is widely available.

The most prevalent Project Management document is the Project Management Body of Knowledge (PMBOK) provided by the Project Management Institute with the objective of serving as reference to Project Management related courses. PMBOK's knowledge area is used as a reference in this paper to define the Project Management knowledge's hierarchical structure. This guide identifies a comprehensive set of Project Management definitions which are "good practice" and "generally recognized". They are organized into five generic process groups and nine Project Management knowledge areas (shown in Table 1), which determine the scope of what is generally understood to be Project Management [7].

However, the guide does not have enough information that allows automatic classification of learning materials according to the hierarchical structure defined for Project Management. Also, PMBOK does not provide a discipline approach to assign tasks and responsibilities of knowledge areas using relationships among concepts or precise properties within the Project Management area. Hence, RUP was also used to define the relationships among the main concepts, which are: Discipline, Role, Artifact and Activity. Although RUP is a software engineering process, the concept of discipline can be related to PMBOK knowledge areas, as shown in Table 1.

Table 1. Relationship between the PMBOK knowledge areas and RUP disciplines

\begin{tabular}{|l|l|}
\hline \multicolumn{1}{|c|}{$\begin{array}{c}\text { PMBOK } \\
\text { Knowledge Area }\end{array}$} & \multicolumn{1}{|c|}{ RUP Discipline } \\
\hline $\begin{array}{l}\text { Project Integration } \\
\text { Management }\end{array}$ & $\begin{array}{l}\text { Project Management } \\
\text { Requirements } \\
\text { Deployment } \\
\text { Configuration \& Change Management }\end{array}$ \\
\hline $\begin{array}{l}\text { Project Scope } \\
\text { Management } \\
\text { Requirements } \\
\text { Configuration \& Change Management }\end{array}$ \\
\hline $\begin{array}{l}\text { Project Time } \\
\text { Management }\end{array}$ & Project Management \\
\hline $\begin{array}{l}\text { Project Cost } \\
\text { Management }\end{array}$ & Project Management \\
\hline $\begin{array}{l}\text { Project Quality } \\
\text { Management }\end{array}$ & $\begin{array}{l}\text { Project Management } \\
\text { Configuration \& Change Management }\end{array}$ \\
\hline $\begin{array}{l}\text { Project Human } \\
\text { Resource } \\
\text { Management }\end{array}$ & Project Management \\
\hline $\begin{array}{l}\text { Project } \\
\text { Communications } \\
\text { Management }\end{array}$ & Project Management \\
\hline $\begin{array}{l}\text { Project Risk } \\
\text { Management }\end{array}$ & Project Management \\
\hline $\begin{array}{l}\text { Project } \\
\text { Procurement } \\
\text { Management }\end{array}$ & Requirements \\
\hline
\end{tabular}

\subsection{Development of Ontology}

There is no one "correct" way or methodology for developing ontologies. The method for development of ontologies proposed by [4] is followed in this paper. According to the proposed approach, ontology development involves the following six basic steps. The general stages in the design and development of ontology are as follows:

\section{- Step 1 - ENUMERATE IMPORTANT TERMS IN} ONTOLOGY

To build a glossary for Project Management, we collected the terms from PMBOK and software development area.

- Step 2 - DEFINE THE CLASSES AND THE CLASS HIERARCHY

The main goal of this step is the creation of a set of preliminary concepts and the categorization of those terms into concepts. Using the top-down strategy we tried to fit the terms and concepts into the metaconcept.

- Steps 3 \& 4 - DEFINE THE PROPERTIES OF CLASSES - SLOTS, DEFINE THE FACETS OF THE SLOTS

This step is used to create relationships between the concepts. 


\section{- Step 5: GENERATION OF INSTANCE}

\subsection{OnrepRUP: Ontology Representation of RUP}

RUP expresses each discipline in terms of its key elements: roles (who performs activities which have input and output artifacts), activities (how they perform the tasks), and artifacts (what the activity achieves). A role defines the behavior and responsibilities of an individual, or a set of individuals working together as a team. It provides general description of the role and the artifacts and activities for which the role is responsible. An activity is a piece of task a role performs. It describes the role responsible for the activity and the artifact(s) needed as input and the artifact(s) produced as output. An artifact is a document, model, or model element produced, modified, or used by a process. It describes the role responsible for artifact. Other elements supplement these three key elements, such as work guidelines, artifact guidelines, concepts, templates, reports, checkpoints, whitepapers, roadmaps and tool mentors [12].

OnrepRUP was developed with Discipline concept and its relationship to the key concepts Artifact, Role and Activity. Relationships and their properties created for these four concepts are shown in Table 2.

Table 2. Classes and properties from OnrepRUP

\begin{tabular}{|l|l|l|l|}
\hline $\begin{array}{c}\text { Domain } \\
\text { Class }\end{array}$ & \multicolumn{1}{|c|}{$\begin{array}{c}\text { Range } \\
\text { Class }\end{array}$} & \multicolumn{1}{|c|}{ Property } & $\begin{array}{l}\text { Special Property } \\
\text { (inverse) }\end{array}$ \\
\hline $\begin{array}{l}\text { Artifact } \\
\text { Task } \\
\text { Role }\end{array}$ & $\begin{array}{l}\text { Disciplin } \\
\text { e }\end{array}$ & hasDomain & isDomainOf \\
\hline $\begin{array}{l}\text { Disciplin } \\
\text { e }\end{array}$ & $\begin{array}{l}\text { Artifact } \\
\text { Task } \\
\text { Role }\end{array}$ & isDomainOf & hasDomain \\
\hline Role & Artifact & $\begin{array}{l}\text { hasConsult } \\
\text { hasResponsible }\end{array}$ & $\begin{array}{l}\text { isConsultedBy } \\
\text { isResponsibleFor }\end{array}$ \\
\hline Artifact & Role & $\begin{array}{l}\text { isConsultedBy } \\
\text { isResponsibleFor }\end{array}$ & $\begin{array}{l}\text { hasConsult } \\
\text { hasResponsible }\end{array}$ \\
\hline Role & Activity & hasPerform & IsPerformerOf \\
\hline Activity & Role & IsPerformerOf & hasPerform \\
\hline
\end{tabular}

The general proposed hierarchy is presented in Fig 1. The PMLearningMaterial class was created to group the PMBOK knowledge areas. RupCoreElements class was created to group the derivative concept classes: Discipline, Artifact, Role and Activiy.

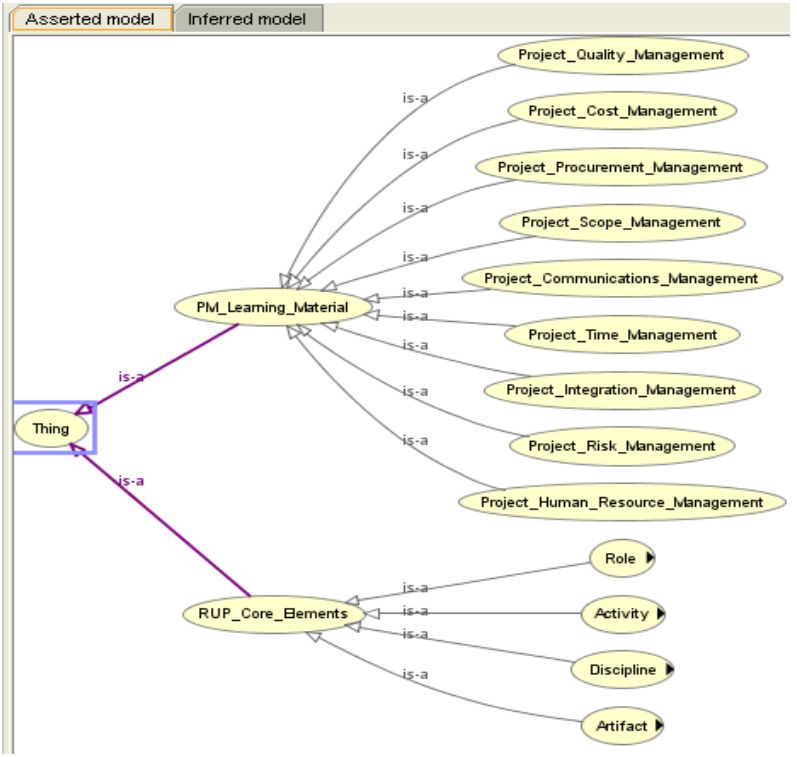

Fig 1: OnrepRUP general hierarchy

The Discipline class consists of nine disciplines that represent the RUP model. Discipline class and other classes Activity, Role and Artifact are represented by the relation "isDomainOf" as shown in Fig 2.

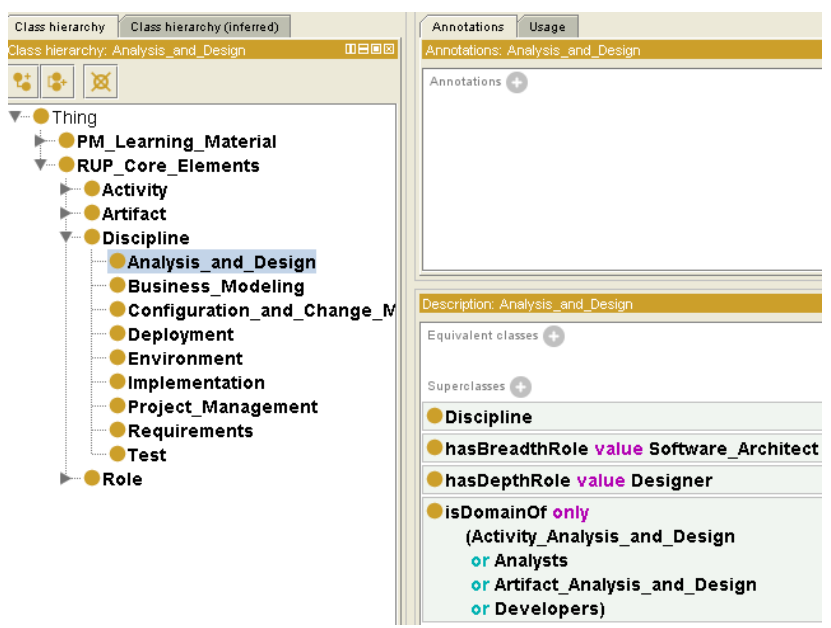

Fig 2: Discipline class

Similarly, classes Artifact, Role and Activity were related to the Discipline class using "hasDomain" property. Fig 3 shows an example of "hasDomain" property relating Artifact and Discipline classes. Subclasses of artifact identify each of nine disciplines proposed in the RUP model using this relationship. 


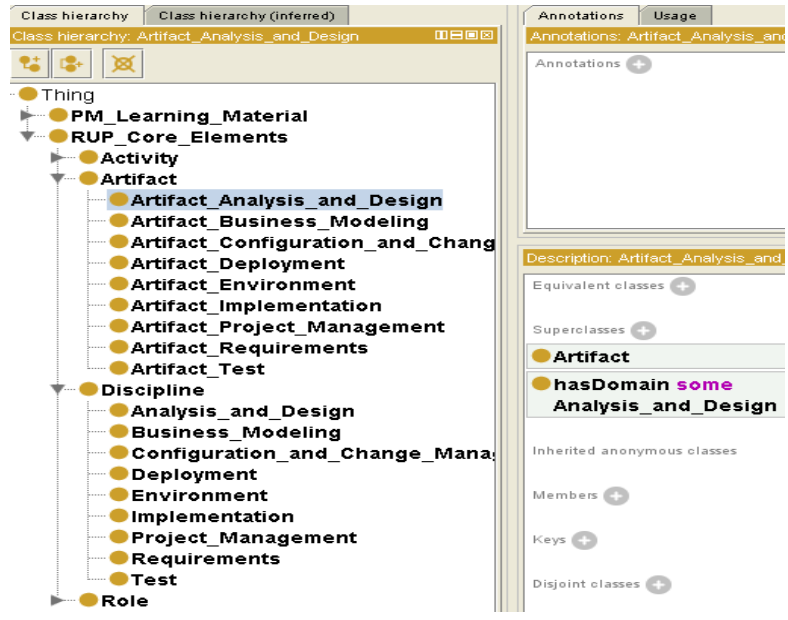

Fig 3: hasDomain property

The Role class consists of six group of roles created within the RUP, namely: Analysts, Developers, General Roles, Manager, Production Support and Testers. Furthermore, instance of each roles are related to the instance of Artifact using two relationships "hasConsult" and "hasResponsible" as shown in Fig 4.

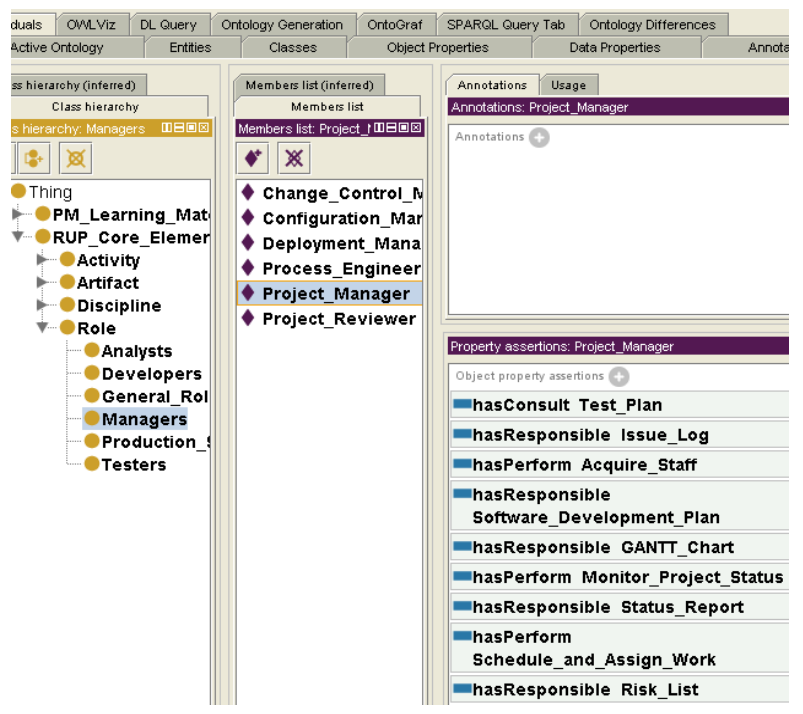

Fig 4: Relation between Role's subclasses and Artifact

The Activity class was created to represent the activity of the RUP model. The Activity class has direct relationship with the Role class through the "hasPerform" property as shown in Fig 5.

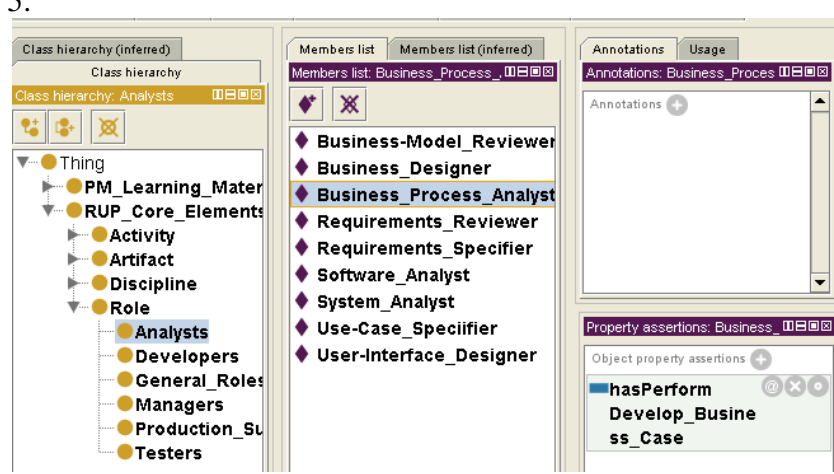

Fig 5: Relation between Role's subclasses and Activity

\subsection{Project Management Learning Materials Ontology}

After the ontology structure for RUP elements are established, it is then necessary to enable automatic classification of learning materials within Project Management domain. The PMLearningMaterial class was created to represent the Project Management learning materials which represent the ten PMBOK's areas. Each PMBOK's areas are assigned to the instance of learning material, as shown in Fig 6.

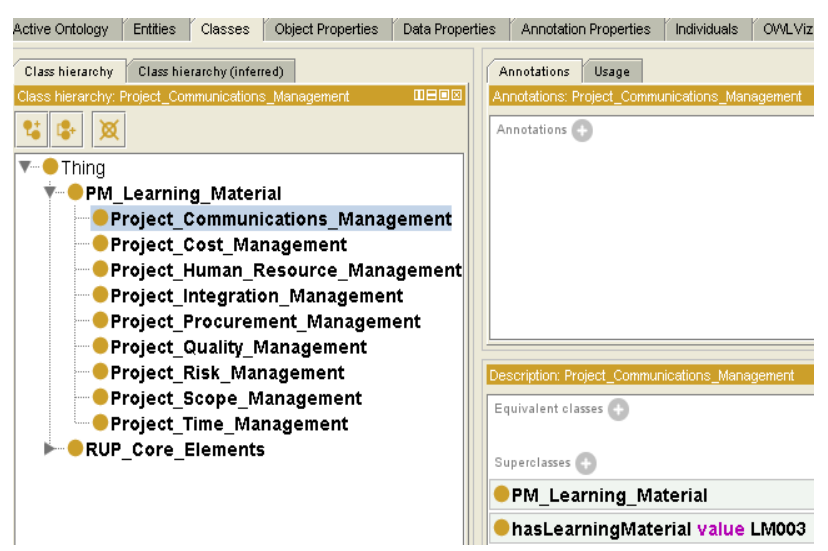

Fig 6: Learning Materials according to the PMBOK

In order to recommend the learning material to the three concepts Artifact, Role and Activity "isRecommendedTo" property was created. Below table shows the relation of three concepts Artifact, Role and Activity to the learning material using "isRecommendedTo" property.

Table 3. isRecommendedTo property

\begin{tabular}{|c|c|c|c|}
\hline $\begin{array}{c}\text { Domain } \\
\text { Class }\end{array}$ & $\begin{array}{c}\text { Range } \\
\text { Class }\end{array}$ & Property & $\begin{array}{c}\text { Special } \\
\text { Property } \\
\text { (inverse) }\end{array}$ \\
\hline $\begin{array}{c}\text { LearningM } \\
\text { aterial }\end{array}$ & $\begin{array}{c}\text { Artifact } \\
\text { Activity } \\
\text { Role }\end{array}$ & $\begin{array}{c}\text { isRecommen } \\
\text { dedTo }\end{array}$ & $\begin{array}{c}\text { hasRecomm } \\
\text { endation }\end{array}$ \\
\hline $\begin{array}{c}\text { Artifact } \\
\text { Activity } \\
\text { Role }\end{array}$ & $\begin{array}{c}\text { LearningM } \\
\text { aterial }\end{array}$ & $\begin{array}{c}\text { hasRecomme } \\
\text { ndation }\end{array}$ & $\begin{array}{c}\text { isRecomme } \\
\text { ndedTo }\end{array}$ \\
& & & \\
\hline
\end{tabular}

Through the related recommendation it is possible to classify the material according to the PMBOK's knowledge areas. Thus, it is possible to recommend the learning material for the use of a specific artifact, such as a Use cases; the execution of a specific activity, such as Develop iteration plan; or the execution of a specific role, such as Software Analyst. For example, a learning material will be classified to atleast one instance of the Artifact, Role or Activity classes using the "isRecommendedTo" property as shown in Fig 7. 


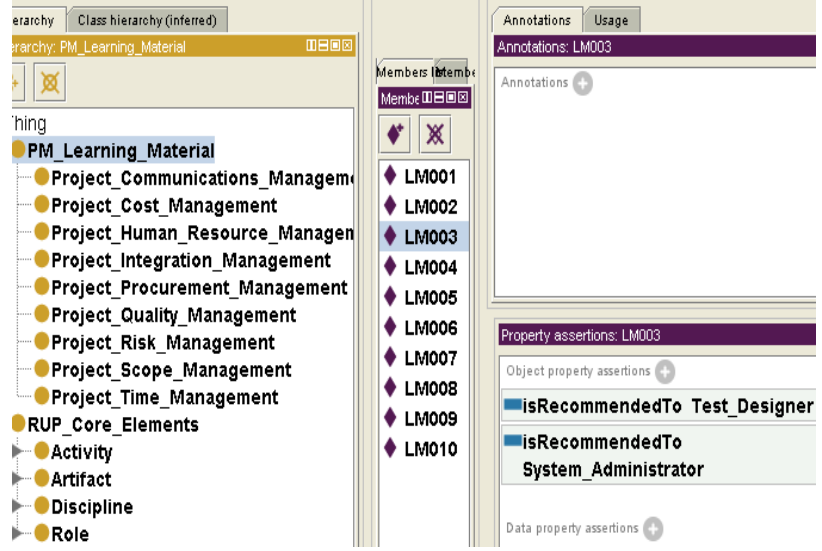

Fig 7: isRecommendedTo Property

This type of recommendation helps to obtain a precise classification of learning materials when there is no formal knowledge about to which knowledge area the material belongs to.

\section{Results}

The proposed ontology could be used in the e-learning environment to share the knowledge related to the Project Management area. This ontology will help the project engineers in two areas. First, it will help to classify the learning materials within the appropriate domain as the user may not have enough knowledge to classify the correct materials. Second, it will assist to recommend the learning materials within the domain. These two cases have been explained with help of proposed ontology in the following sections. The simulations were created using the Protégé 4.2 alpha tool. The Pellet reasoner was used to classify the learning materials.

$\square$ Case 1 - Learning Materials Classification

Project Management learning material instances are added in the Protégé, as shown in Fig 8. Also "isRecommendedTo" property was used to make recommendations to the instances of three classes Artifact, Role and Activity.

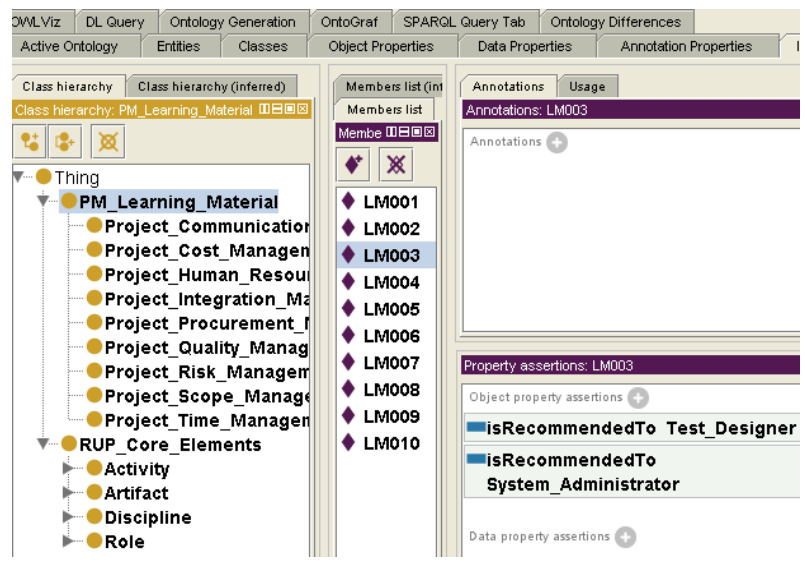

Fig 8: Learning materials instances included using Protégé Below table shows the values assigned to the "isRecommendedTo" property for each one of the learning materials.
Table 4. Values assigned to the "isRecommendedTo" property

\begin{tabular}{|c|c|c|c|}
\hline $\begin{array}{l}\text { Id. } \\
\text { Material }\end{array}$ & $\begin{array}{l}\text { Recommend } \\
\text { ation for } \\
\text { Artifact }\end{array}$ & $\begin{array}{l}\text { Recommend } \\
\text { ation for } \\
\text { Role }\end{array}$ & $\begin{array}{l}\text { Recommend } \\
\text { ation for } \\
\text { Activity }\end{array}$ \\
\hline $\begin{array}{l}\text { Learning } \\
\text { Material } \\
001\end{array}$ & $\begin{array}{l}\text { Programming } \\
\text { Guidelines }\end{array}$ & $\begin{array}{l}\text { Requirements } \\
\text { Reviewer }\end{array}$ & \\
\hline $\begin{array}{l}\text { Learning } \\
\text { Material } \\
002\end{array}$ & Risk List & & $\begin{array}{l}\text { Update } \\
\text { Change } \\
\text { Request }\end{array}$ \\
\hline $\begin{array}{l}\text { Learning } \\
\text { Material } \\
003\end{array}$ & & $\begin{array}{l}\text { Test Designer } \\
\text { System } \\
\text { Administrator }\end{array}$ & \\
\hline $\begin{array}{l}\text { Learning } \\
\text { Material } \\
004\end{array}$ & & & $\begin{array}{l}\text { Develop } \\
\text { Business } \\
\text { Case } \\
\text { Schedule and } \\
\text { Assign Work }\end{array}$ \\
\hline $\begin{array}{l}\text { Learning } \\
\text { Material } \\
005\end{array}$ & $\begin{array}{l}\text { User Interface } \\
\text { Guidelines }\end{array}$ & & \\
\hline $\begin{array}{l}\text { Learning } \\
\text { Material } \\
006\end{array}$ & $\begin{array}{l}\text { Measurement } \\
\text { Plan }\end{array}$ & & \\
\hline $\begin{array}{l}\text { Learning } \\
\text { Material } \\
007\end{array}$ & & & Report Status \\
\hline $\begin{array}{l}\text { Learning } \\
\text { Material } \\
008\end{array}$ & $\begin{array}{l}\text { Review } \\
\text { Record } \\
\text { Software } \\
\text { Development } \\
\text { Plan } \\
\text { (Training- } \\
\text { Plan) } \\
\end{array}$ & & \\
\hline $\begin{array}{l}\text { Learning } \\
\text { Material } \\
009\end{array}$ & $\begin{array}{l}\text { Project Plan } \\
\text { (updated) }\end{array}$ & & \\
\hline $\begin{array}{l}\text { Learning } \\
\text { Material } \\
010\end{array}$ & & $\begin{array}{l}\text { System } \\
\text { Analyst }\end{array}$ & \\
\hline
\end{tabular}

It is possible to verify for the learning materials by knowledge areas defined in the PMBOK as shown in Fig 9. The learning materials are classified in three knowledge areas, one of them by artifact recommendation, and the other two by Role and Activity. The proposed ontology can be used to help filter consistent recommendations among Artifact, Role and Activiy classes.

For example, it is possible to retrieve all the learning materials related to the Project Communications Management area. 


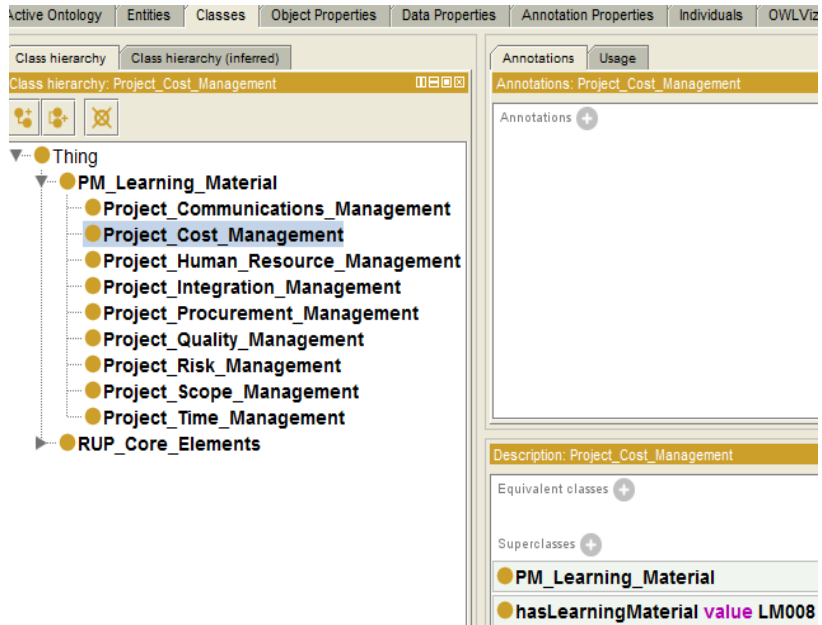

Fig 9: Learning Materials classification

Case 2 - Learning Materials Recommendation

Case 2 allows the users to find all the learning materials according to the recommendations done by the three classes Artifact, Role and Activity.

SPARQL was used to simulate a sample of these cases possibilities. The SPARQL is an RDF query language, that is, a query language for databases, able to retrieve and manipulate data stored in Resource Description Framework format [13]. Fig 10 shows the result obtained using SPARQL query which retrieves learning materials recommended by Roles.

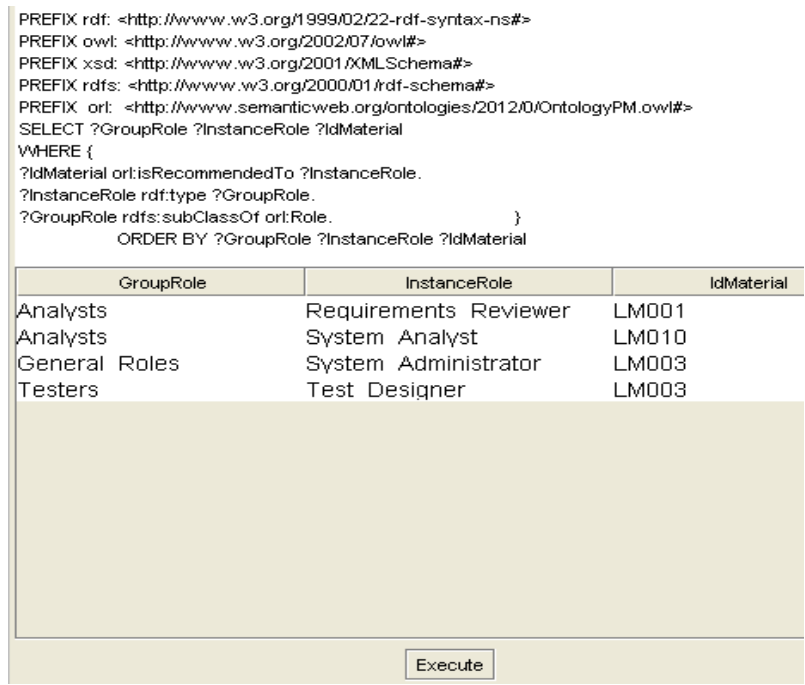

Fig 10: Query using SPARQL by Role

Queries can be executed to obtain learning materials recommended by Artifacts and Activity as well as shown in Fig 11 and 12 .

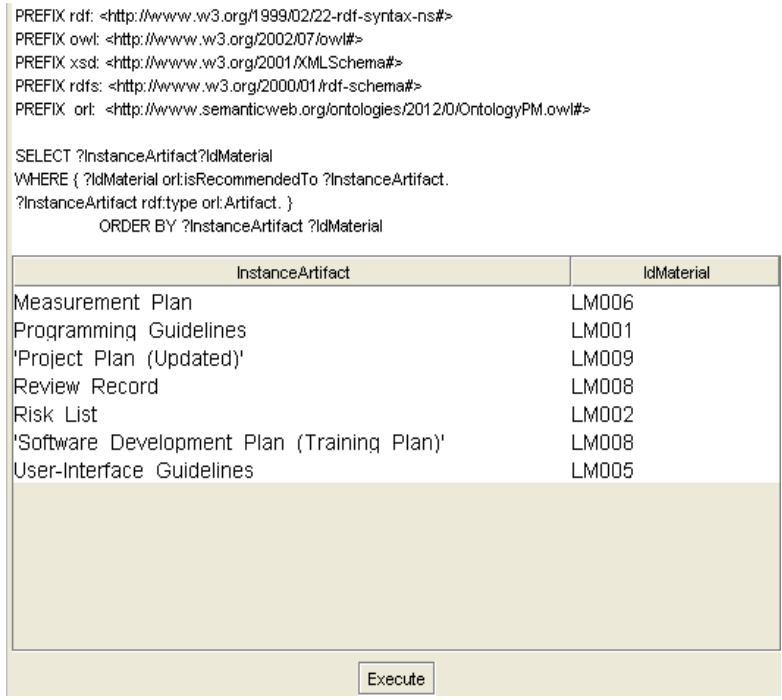

Fig 11: Query using SPARQL by Artifact

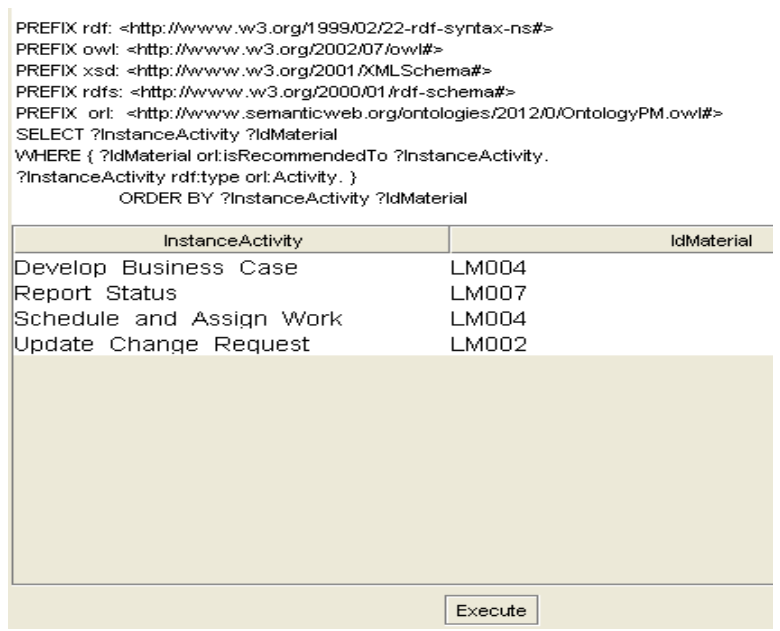

Fig 12: Query using SPARQL by Activity

It is also possible to add new recommendations to the learning materials according to the use. For example, a learning material that was added with the Requirement Reviewer role may also be recommended to the Programming Guidelines Artifact. Hence, the detail for the recommendation and retrieval of material becomes more efficient and precise.

\section{Conclusion}

This paper proposed an ontology to automatically classify learning materials related to the Project Management knowledge area. Main structure of PMBOK knowledge area was used to define the ontology. RUP was used to define the concept and relationships among three classes Artifact, Activity and Role. The RUP was used to add axioms to represent the relationships between concepts and enable the reasoning to the $\mathrm{PMBOK}$ knowledge area according to recommendations. It aims to facilitate the search for these materials.

Some experiments were performed to automatically classify the learning materials in the Project Management knowledge areas. Furthermore, the ontology provides views of the learning materials recommended under three aspects artifacts, activity and role. This diversity can be another facilitator for retrieving the desired material. 
The proposed ontology will be integrated to a self-learning environment, and experiments with Project Management students and professionals will be performed in order to evaluate the proposal.

\section{References}

[1] Wei Hu, Tianzhou Chen, and Qingsong Shi, "Collaborative Web-Based E-learning Environment for Information Security Curriculum" World Academy of Science, Engineering and Technology, 53, 2009.

[2] Joselaine Valaski, Andreia Malucelli, Sheila Reinehr, Ricardo Santos,"Ontology to Classify Learning Material in Software Engineering Knowledge Domain”, 2011.

[3] Cornelius Wille, Alain Abran, Jean Marc Desharnais, Reiner R. Dumke," The quality conceps and subconcepts in SWEBOK: An ontology challenge", 2003.

[4] Noy, N. F. and McGuinness, D. L. "Ontology Development 101: A Guide to Creating Your First Ontology". Stanford Knowledge Systems Laboratory Technical Report KSL-01-05 and Stanford Medical Informatics Technical Report SMI-2001-0880, 2001.

[5] Guarino, N," Formal Ontology and Information Systems", (pp. 3-15). Amsterdam, Netherlands: IOS Press, 1998.

[6] Duncan, W. R.; A Guide to the Project Management Body of Knowledge, PMI Standards Committee, Project Management Institute, 1996.

[7] Sven Abels, Frederik Ahlemann, Axel Hahn, Kevin Hausmann, and Jan Strickmann," PROMONT - A
Project Management Ontology as a Reference for Virtual Project Organizations", OTM Workshops, LNCS 4277, pp. $813-823,2006$.

[8] Robert T. Hughes,"Project management process ontologies: a proof of concept", 2010.

[9] Sarantis, D. Askounis, D., "A project management ontology as a reference for e-Government projects" Internet Technology and Secured Transactions, 978-14244-5647-5, ICITST, 2009.

[10] Daniel Antonio Callegari, Ricardo Melo Bastos, "Project Management and Software Development Processes: Integrating RUP and PMBOK”, International Conference on Systems Engineering and Modeling,IEEE, 2007.

[11] Maya Kaner and Reuven Karni, "Experience Management within Project Management Processes", 2001.

[12] PRJ270: Essentials of Rational Unified Process, Module 3: RUP Structure and Navigation, PPT Presentation, accessed 2012

[13] SPARQL: http://en.wikipedia.org/wiki/SPARQL, accessed June 2012.

[14] Stanford. "The Protégé Ontology Editor and Knowledge Acquisition System", http://protege.stanford.edu/index.html, accessed June 2012. 